\title{
ASSESSMENT OF JOB SATISFACTION AND STRESS LEVEL OF OCCUPATIONAL SAFETY SPECIALISTS ${ }^{(1)}$
}

\section{İŞ GÜVENLIĞİ UZMANLARININ ISS TATMINI VE STRES DÜZEYLERINIIN DEĞERLENDİRILMESI}

\author{
Feray (Küçükbaş) DUMAN', Selçuk Bora ÇAVUŞOĞLU⿱2 , C. Nihal YURTSEVEN', \\ Eray YURTSEVEN ${ }^{4}$
}

${ }^{1-2-3}$ Istanbul University-Cerrahpasa, Faculty of Sport Science, Department of Sport Management, Avcrlar Istanbul / Turkey

${ }^{4}$ Istanbul University Faculty of Medicine/ Department of Biostatistics, Istanbul / Turkey

ORCID ID: 0000-0002-8265-4037', 0000-0003-4163-9652², 0000-0001-8201-0752

0000-0003-0565-6407

Öz: Giriş: Bu çalışmada iş güvenliği uzmanlarının iş tatminlerinin, görevlerini yerine getirmede olumlu bir rol oynadığı fikrinden yola çıkılmıştır. Bu nedenle iş tatmini ölçülmeli, analiz edilmeli ve bu bağlamda kapsamlı bir anlayışa sahip olmak için daha fazla çalışılmalıdır. Yöntem: Bu tanımlayıcı çalışma Nisan-Haziran 2018 tarihleri arasında İstanbul Üniversitesi Sağlık Bilimleri Enstitüsü İş Sağlığı ve Güvenliği Programı'nda gerçekleştirilmiştir. Çalışmada örneklem uygulanmamış olup, İş Sağlığı ve Güvenliği bölümündeki 300 öğrenci çalışmaya dahil edilmiştir. Bu çalışmada kullanılan veriler, katılımcıların sosyo-demografik özelliklerini, iş tatminine yönelik tutumlarını ve davranışlarını belirlemek için 29 maddeden oluşan bir anket formu ile elde edilmiștir. Tartışma: Tüm sosyo-demografik faktörler analiz edilmiş ancak bulunan önemli değişkenler iş sağlığı ve güvenliği uzmanlık belgesinin türü ve iş durumu olmuştur ( $\mathrm{p}<0.05$ ), diğer faktörler önemli bir etkiye sahip değildir. B grubu iş güvenliği uzmanları iş tatmini ve gelecekteki kariyeri konusunda daha iyimserken, $\mathrm{C}$ grubu iș güvenliği uzmanları gelecek beklentileri ve başkalarının olası rehberliği konusunda daha temkinlidir. Sonuç: Bu durum eğitim süresi ve Calışma ve Sosyal Güvenlik Bakanlığı tarafından yapılan sınavlarla açıklanabilir. Bulgular, $\mathrm{C}$ grubu iş güvenliği uzmanları için daha iyi bir motivasyon ve daha yumuşak bir geçiş sürecine duyulan ihtiyacı ortaya koymaktadır.

Anahtar Kelimeler: İş Tatmini, İş Güvenliği Uzmanı, Kaza, Sağlık
Abstract: Aim: This study departs from the idea that job satisfaction of the Occupational Safety Specialists play a positive role in this important mission and, for this reason, their job satisfaction should be measured, analyzed and further studied to have comprehensive understanding in this context. Method: This descriptive study was performed between April and June 2018 at the Istanbul University Health Sciences Institute Occupational Health and Safety Program. The study did not use sampling, as all " 300 students in the department of Occupational Health and Safety were included in the study. The data used in this study were obtained through a self-administered questionnaire with 29 items to determine participants' socio-demographic characteristics, their knowledge, attitude and behaviour towards job satisfaction. Results: All sociodemographic factors were analysed, but the only significant variables found were type of occupational health and safety expertise document and types of work status $(p<0.05)$, none of the other factors had a significant effect. Group B is more optimistic about their job satisfaction and future career, while Group $\mathrm{C}$ is more cautious about their future prospects and possible guidance of others. Conclusion: This can be explained by training period and examinations conducted by the Ministry of Labor and Social Security. The findings suggest the need for a better motivation and a smoother process for Group $\mathrm{C}$ in health and safety business.

Key Words: Job Satisfaction, Occupational Safety Specialist, Accident, Health

\section{Doi: 10.17363/SSTB.2019.31.3}

(1) Corresponding Author: Feray (Küçükbaş) DUMAN, Istanbul University-Cerrahpasa, Faculty of Sport Science, Department of Sport Management, Avcilar, Istanbul/Turkey,feray.kucukbas@gmail.com, Arrival Date/Received: 01.02.2019, Accepted / Accepted: 03.06.2019,Type of Article: (Application and Research) Conflict of Interest: None, Ethics Committee Report: None 
International Refereed Academic Journal of Sports, Health and Medical Sciences April - May - June Issue: 31 Spring Summer Semester Year: 2019

Uluslararası Hakemli Akademik Spor Sağlık ve Tıp Bilimleri Dergisi

Nisan - Mayıs - Haziran Sayı: 31 İlbahar Yaz Dönemi Yıl: 2019 ID:448 K:475

ISSN Print: 2146-8508 Online 2147-1711

(ISO 18001-OH-0090-13001706 / ISO 14001-EM-0090-13001706 / ISO 9001-QM-0090-13001706 / ISO 10002-CM-0090-13001706) (TRADEMARK)

(2015/04315- 2015-GE-18972)

\section{INTRODUCTION}

Humankind has to be a part of the working life in order to sustain his life and to live a life that is worthy of himself. In today's rapidly developing and changing world, significant changes are experienced in industrialization as well in parallel with the developments experienced in the scientific and technological fields. When assessed in the light of the work methods, work environment and the employees, this situation also leads to numerous health and safety risks (Alali, et al., 2018). As a result of the mechanization that increases with industrialization and the developments in technology, the risks that the employees are exposed to increase, and the formation of different lines of work and the increase in the number of employees makes the working life more and more complex (Durdu, 2014).

The concept of "Occupational Health and Safety", which expresses the multi-disciplinary efforts realized in order to protect the health of the employees from the negative impacts that may emerge in the work environment and to ensure the sustainability and efficiency of production, becomes more important each day (Pekşen, 2017).

A work-related accident is defined as "an event that occurs at the workplace or as a result of the carrying out of the work and causes death or disables the integrity of the body emotionally or physically" according to Article 3 of the Occupational Health and Safety Code numbered 6331.

Work-related accidents usually occur as a result of the interaction of the employee with the machinery and equipment present in the workplace environment and the production area (Tsai and Bruck, 2009).Work-related accidents, which have maintained their importance in all historical eras, have been observed in a more wide-spread manner with globalization and industrialization and had an impact on economy (Durdu,2014).

"In our country, an average of 4 people lose their lives in a day as a result of work-related accidents and occupational illnesses while 9 people join the army of disabled persons, the number of which reach 10 million. The loss of working days that our country incurs as a result of this, health services including medicines and doctors payments, the indemnities paid, temporary and permanent incapacity pensions, damages to equipment, the loss of efficiency and output resulting from the loss of motivation of the workers at the workplace which results from the accident and continues for days total up to 4 percent of the national income according to the researches conducted and the official numbers"(http://www.vergivekanunlar.com/is-saglg-ve-guvenligi-yasas5-isverenin/). 


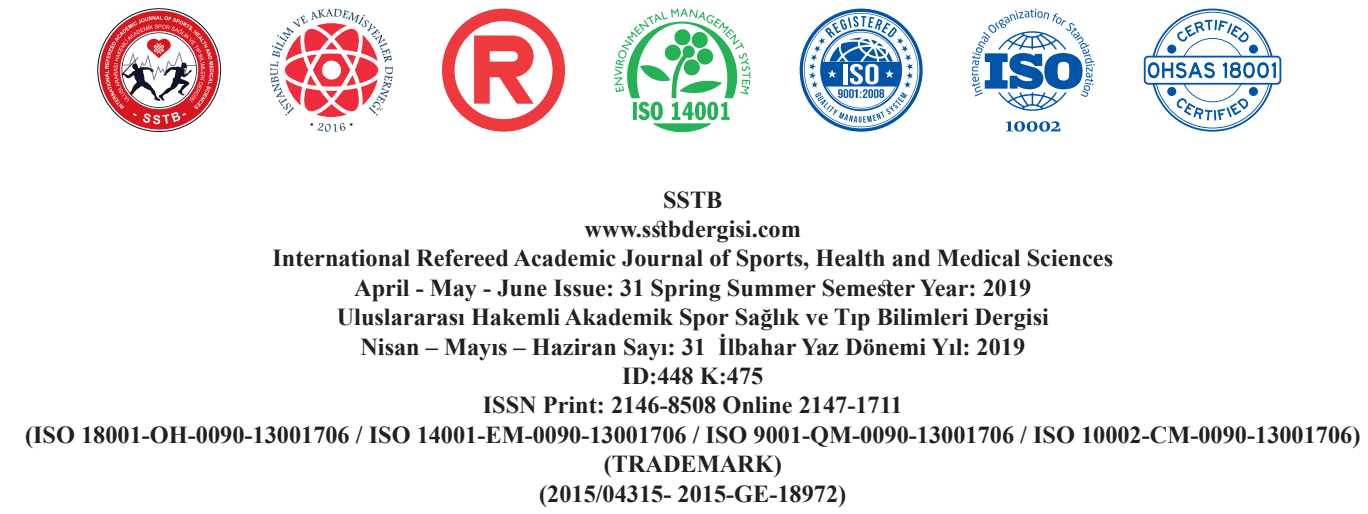

The mortalities that occur in our country as a result of work-related accidents are much higher than the average in the world and the European Union When the rate of workrelated accidents that result in mortalities are examined, Turkey ranks the third in the world and the first in Europe (Öçal and Çiçek, 2017).

In our country, the data concerning the workrelated accidents are registered by SGK. When this data is examined; The total number of work-related accidents that occurred in Turkey in 2015 is 241.547 , the number of mortalities that occurred as a result of workrelated accidents is 1252 . When these values are examined in the European Union, it is observed that the total number of work-related accidents is 2.297 .752 and the number of mortalities that occurred is 3709 (Öçal and Çiçek, 2017).

When the rate of work-related accidents and mortalities that result from work-related accidents in the European Union, the active population of which is approximately four times our country, is compared with Turkey, the situation can be seen more clearly (Öçal and Çiçek, 2017).

There are numerous social, legal and economic impacts and consequences of occupational health and safety measures, which are of great importance for the prevention of work- related accidents, not being taken. When the work-related accidents are seen from an economic perspective, the employees, the employers and the government are significantly impacted from this situation (Narter, 2015).

A meticulous assessment is required for the reduction of the negative impacts of the workrelated accidents, which have numerous negative consequences in terms of the government, the employees and the employers, and the resolution of the problem (Aydin,2013). From this perspective, the efforts of occupational safety specialist that know the nature of the work, the functions of the equipment used in the production area and the safety measures pertaining to such is of great importance (Karakaya and Sanc1, 2017).

There are 84 Occupational Health and Safety programs providing education in affiliation with Institutes of Science and Technology, Health and Social Sciences, opened for the purpose of Graduate Education within the scope of 185 universities affiliated with the Higher Education Institution in Turkey. 40 of these programs are masters with thesis programs while 44 of them are non-thesis mater's programs. "The duties and obligations of the occupational safety specialist concerning the performance of the works regarding the determining and prevention of the occupational risks and ensuring protection have been determined with the Regulation Concerning the 
International Refereed Academic Journal of Sports, Health and Medical Sciences April - May - June Issue: 31 Spring Summer Semester Year: 2019

Uluslararası Hakemli Akademik Spor Sağlık ve Tıp Bilimleri Dergisi

Nisan - Mayıs - Haziran Sayı: 31 İlbahar Yaz Dönemi Yıl: 2019 ID:448 K:475

ISSN Print: 2146-8508 Online 2147-1711

(ISO 18001-OH-0090-13001706 / ISO 14001-EM-0090-13001706 / ISO 9001-QM-0090-13001706 / ISO 10002-CM-0090-13001706) (TRADEMARK)

Duties, Authorizations, Responsibilities and Trainings of the Occupational Safety Specialists" (Arslan and Ulubeyli, 2016).

In order for the occupational safety specialist that perform such an important task to work in an efficient and effective manner, the satisfaction they get from their jobs is of great important (Karakaya and Sanc1, 2017). That's because their reaction to the job and the work is expressed with their approach pertaining the work. This approach is reflected as positive or negative according to their level of job satisfaction and job gratification (Eğinli, 2009).

Working is not just a method used for persons to sustain their lives and meet their needs. Humans are also beings with psychological and social needs. For this reason, job satisfaction and motivation emerge as important concepts in work life (Y1lmaz, 2014).

Occupational safety specialist are carrying out important tasks for the protection of the physical and mental health of the employees, the necessary safety measures to be taken for the employees to work more efficiently and the human resources to be used effectively and efficiently in businesses. For this reason, the job satisfaction of the occupational experts to be of a high level is of significance both in terms of the increasing of their efficiency and also in terms of setting an exam- ple for the employees of the business (Karakaya and Sanc1, 2017).

In this study, the purpose is to examine the job satisfaction of the Occupational Safety Specialist that have an Occupation Health and Safety degree from a university. The work life is full of complications and occupational safety specialists are responsible to address a certain amount of these challenges in the daily routine of the workers. This study departs from the idea that job satisfaction of the Occupational Safety Specialists play a positive role in this important mission and, for this reason, their job satisfaction should be measured, analyzed and further studied to have comprehensive understanding in this context. This article utilizes a quantitative data on Occupational Safety Specialist with a degree in this area to shed light on the important question of to what extent Specialists have satisfied by doing their jobs since their satisfaction will eventually have a considerable influence on health and safety situation of the workers in work life.

\section{AIM}

This study departs from the idea that job satisfaction of the Occupational Safety Specialists play a positive role in this important mission and, for this reason, their job satisfaction should be measured, analyzed and further 
International Refereed Academic Journal of Sports, Health and Medical Sciences

April - May - June Issue: 31 Spring Summer Semester Year: 2019

Uluslararası Hakemli Akademik Spor Sağlık ve Tıp Bilimleri Dergisi

Nisan - Mayıs - Haziran Sayı: 31 İlbahar Yaz Dönemi Yıl: 2019

ID:448 K:475

ISSN Print: 2146-8508 Online 2147-1711

(ISO 18001-OH-0090-13001706 / ISO 14001-EM-0090-13001706 / ISO 9001-QM-0090-13001706 / ISO 10002-CM-0090-13001706) (TRADEMARK)

(2015/04315- 2015-GE-18972)

studied to have comprehensive understanding in this context.

\section{RESEARCH METHOD}

This descriptive study was performed between April and June 2018 at the Istanbul University Health Sciences Institute Occupational Health and Safety Program. The study did not use sampling, as all "300 students in the department of Occupational Health and Safety were included in the study. The data used in this study were obtained through a self-administered questionnaire with 29 items to determine participants' socio-demographic characteristics, their knowledge, attitude and behaviour towards job satisfaction. The first part contains basic demographic details, such as age, gender, marital status and the second section contains 20 items which measures the personal job satisfaction. The questions ( $\mathrm{n}=$ 20) contained attitudinal statements using a five-point Likert scale ("Not Satisfied (1)" to "Highly Satisfied (5)").

The survey form was developed through an online platform, and delivered to invitees via e-mail. This invitation was repeated twice with a week interval. The data was analysed using SPSS (Statistical Package for Social Sciences) 15.0. Following the statistical evaluation of data and the summarization of frequencies and percentages, students t-test ANOVA and correlation analysis were used. All statistical analysis was done at 95\% confidence level ( $\mathrm{p} \leq 0.05$ was considered significant). The choice of choosing students at Turkish universities is mainly due to job consciousness of the Specialists with a degree and reliable of the data from an elite group in the research.

\section{RESULTS}

A total of 300 graduate students participated in our study. $96(32 \%)$ of them completed questionnaires. The students who participated in the survey were aged between 26-50 and total 96 graduate students who participated in the study 65 were male $(67 \%)$ and 31 were female $(33 \%)$.

As Table 1 indicates, all socio-demographic factors were analysed, but the only significant variables found were type of occupational health and safety expertise document and types of work status $(p<0.05)$, none of the other factors had a significant effect. 
International Refereed Academic Journal of Sports, Health and Medical Sciences April - May - June Issue: 31 Spring Summer Semester Year: 2019

Uluslararası Hakemli Akademik Spor Sağlık ve Tıp Bilimleri Dergis

Nisan - Mayıs - Haziran Sayı: 31 İlbahar Yaz Dönemi Yıl: 2019 ID:448 K:475

ISSN Print: 2146-8508 Online 2147-1711

(ISO 18001-OH-0090-13001706 / ISO 14001-EM-0090-13001706 / ISO 9001-QM-0090-13001706 / ISO 10002-CM-0090-13001706) (TRADEMARK)

(2015/04315- 2015-GE-18972)

Table 1. Socio-Demographic Characteristics of the Participants

\begin{tabular}{|c|c|c|c|c|c|}
\hline & Variables & $\mathrm{N}$ & $\begin{array}{l}\text { Job Satisfacti- } \\
\text { on Score }\end{array}$ & $\begin{array}{c}\text { Standard } \\
\text { Deviation }(+/-)\end{array}$ & $\mathrm{P}$ \\
\hline \multirow{2}{*}{ Gender } & Male & 65 & 60,55 & 17,54 & \multirow[t]{2}{*}{$>0,05$} \\
\hline & Female & 31 & 63,67 & 12.92 & \\
\hline \multirow{3}{*}{ Marital Status } & Married & 67 & 60,85 & 16.04 & \multirow[t]{3}{*}{$>0,05$} \\
\hline & Single & 26 & 64,42 & 17,12 & \\
\hline & Divorced & 3 & 52,66 & 8,08 & \\
\hline \multirow{2}{*}{ Employment Situation } & Public & 23 & 60,52 & 12,92 & \multirow[t]{2}{*}{$*<0,05$} \\
\hline & $\begin{array}{l}\text { Private } \\
\text { Sector }\end{array}$ & 73 & 64,89 & 17,16 & \\
\hline \multirow{2}{*}{ ISG* Document Type } & C Group & 48 & 60,20 & 17,83 & \multirow[t]{2}{*}{$*<0,05$} \\
\hline & B Group & 48 & 63,91 & 14,52 & \\
\hline
\end{tabular}

*Occupational Health and Safety

Table 2. Job Satisfaction of Occupational Health and Safety Specialists

\begin{tabular}{|c|c|c|c|c|c|c|c|}
\hline No & Questions & $\begin{array}{l}\text { ISG* }^{*} \text { Docu- } \\
\text { ment Type }\end{array}$ & $\begin{array}{l}\text { Not Satis- } \\
\text { fied (1) }\end{array}$ & $\begin{array}{l}\text { Less Sa- } \\
\text { tisfied ( } 2)\end{array}$ & $\begin{array}{c}\text { Medium } \\
\text { Satisfied (3) }\end{array}$ & $\begin{array}{l}\text { Satisfied } \\
\text { (4) }\end{array}$ & $\begin{array}{l}\text { Highly Sa- } \\
\text { tisfied (5) }\end{array}$ \\
\hline \multirow[t]{2}{*}{1} & \multirow{2}{*}{$\begin{array}{l}\text { Opportunity for perma- } \\
\text { nent work }\end{array}$} & Group B & 2 & 11 & 16 & 13 & 6 \\
\hline & & Group C & 0 & 10 & 15 & 17 & 6 \\
\hline \multirow[t]{2}{*}{2} & \multirow{2}{*}{$\begin{array}{l}\text { Opportunity to work } \\
\text { alone }\end{array}$} & Group B & 2 & 13 & 13 & 12 & 8 \\
\hline & & Group C & 3 & 9 & 11 & 17 & 8 \\
\hline \multirow[t]{2}{*}{3} & \multirow{2}{*}{$\begin{array}{l}\text { Opportunity to engage } \\
\text { in different work }\end{array}$} & Group B & 3 & 16 & 9 & 14 & 6 \\
\hline & & Group C & 4 & 12 & 17 & 12 & 3 \\
\hline \multirow[t]{2}{*}{4} & \multirow{2}{*}{$\begin{array}{l}\text { Opportunity to obtain a } \\
\text { status in society }\end{array}$} & Group B & 5 & 7 & 16 & 16 & 4 \\
\hline & & Group C & 5 & 10 & 16 & 9 & 8 \\
\hline \multirow[t]{2}{*}{5} & \multirow{2}{*}{$\begin{array}{l}\text { Manager's attitude } \\
\text { toward workers }\end{array}$} & Group B & 9 & 10 & 11 & 14 & 4 \\
\hline & & Group C & 5 & 13 & 16 & 9 & 5 \\
\hline \multirow[t]{2}{*}{6} & \multirow{2}{*}{$\begin{array}{l}\text { Sufficiency of manager } \\
\text { in decision making } \\
\text { process }\end{array}$} & Group B & 8 & 14 & 11 & 11 & 4 \\
\hline & & Group C & 7 & 10 & 11 & 12 & 8 \\
\hline
\end{tabular}






SSTB

www.sstbdergisi.com

International Refereed Academic Journal of Sports, Health and Medical Sciences

April - May - June Issue: 31 Spring Summer Semester Year: 2019

Uluslararası Hakemli Akademik Spor Sağlık ve Tıp Bilimleri Dergisi

Nisan - Mayıs - Haziran Sayı: 31 İlbahar Yaz Dönemi Yıl: 2019

ID:448 K:475

ISSN Print: 2146-8508 Online 2147-1711

(ISO 18001-OH-0090-13001706 / ISO 14001-EM-0090-13001706 / ISO 9001-QM-0090-13001706 / ISO 10002-CM-0090-13001706) (TRADEMARK)

(2015/04315- 2015-GE-18972)

\begin{tabular}{|c|c|c|c|c|c|c|c|}
\hline \multirow[t]{2}{*}{7} & \multirow{2}{*}{$\begin{array}{l}\text { Opportunity to work } \\
\text { according to one's own } \\
\text { ethical values }\end{array}$} & Group B & 4 & 14 & 12 & 15 & 3 \\
\hline & & Group C & 6 & 9 & 15 & 8 & 10 \\
\hline \multirow[t]{2}{*}{8} & \multirow{2}{*}{$\begin{array}{l}\text { Opportunity to keep a } \\
\text { permanent job position }\end{array}$} & Group B & 3 & 15 & 12 & 14 & 4 \\
\hline & & Group C & 3 & 11 & 6 & 16 & 12 \\
\hline \multirow[t]{2}{*}{9} & \multirow{2}{*}{$\begin{array}{l}\text { Opportunity to help } \\
\text { others }\end{array}$} & Group B & 2 & 15 & 9 & 13 & 9 \\
\hline & & Group C & 1 & 11 & 16 & 10 & 10 \\
\hline \multirow[t]{2}{*}{10} & \multirow{2}{*}{$\begin{array}{l}\text { Opportunity to guide } \\
\text { others }\end{array}$} & Group B & 0 & 15 & 11 & 15 & 7 \\
\hline & & Group C & 2 & 8 & 13 & 19 & 6 \\
\hline \multirow[t]{2}{*}{11} & \multirow{2}{*}{$\begin{array}{l}\text { Opportunity to use } \\
\text { one's talent }\end{array}$} & Group B & 4 & 17 & 9 & 16 & 2 \\
\hline & & Group C & 1 & 17 & 12 & 9 & 9 \\
\hline \multirow[t]{2}{*}{12} & \multirow{2}{*}{$\begin{array}{l}\text { Opportunity to apply } \\
\text { company policy }\end{array}$} & Group B & 3 & 15 & 11 & 16 & 3 \\
\hline & & Group C & 2 & 11 & 12 & 19 & 4 \\
\hline \multirow[t]{2}{*}{13} & \multirow[t]{2}{*}{ My salary } & Group B & 5 & 15 & 17 & 8 & 3 \\
\hline & & Group C & 3 & 15 & 14 & 14 & 2 \\
\hline \multirow[t]{2}{*}{14} & \multirow{2}{*}{$\begin{array}{l}\text { Opportunity for career } \\
\text { development }\end{array}$} & Group B & 10 & 9 & 14 & 13 & 2 \\
\hline & & Group C & 5 & 11 & 12 & 15 & 5 \\
\hline \multirow[t]{2}{*}{15} & \multirow{2}{*}{$\begin{array}{l}\text { Freedom to use one's } \\
\text { own judgement }\end{array}$} & Group B & 4 & 10 & 12 & 18 & 4 \\
\hline & & Group C & 3 & 15 & 9 & 16 & 5 \\
\hline \multirow[t]{2}{*}{16} & \multirow{2}{*}{$\begin{array}{l}\text { Opportunity to use } \\
\text { one's own methods }\end{array}$} & Group B & 3 & 10 & 13 & 15 & 7 \\
\hline & & Group C & 4 & 13 & 13 & 13 & 5 \\
\hline \multirow[t]{2}{*}{17} & \multirow[t]{2}{*}{ Work conditions } & Group B & 8 & 11 & 16 & 11 & 2 \\
\hline & & Group C & 4 & 11 & 18 & 14 & 1 \\
\hline \multirow[t]{2}{*}{18} & \multirow{2}{*}{$\begin{array}{l}\text { Relations among the } \\
\text { fellow workers }\end{array}$} & Group B & 1 & 16 & 11 & 15 & 5 \\
\hline & & Group C & 1 & 12 & 17 & 16 & 2 \\
\hline \multirow[t]{2}{*}{19} & \multirow{2}{*}{$\begin{array}{l}\text { Appreciation in the } \\
\text { business }\end{array}$} & Group B & 9 & 13 & 18 & 6 & 2 \\
\hline & & Group C & 8 & 10 & 16 & 11 & 3 \\
\hline \multirow[t]{2}{*}{20} & \multirow[t]{2}{*}{ Satisfaction in business } & Group B & 7 & 13 & 9 & 13 & 6 \\
\hline & & Group C & 3 & 11 & 16 & 11 & 7 \\
\hline
\end{tabular}

*Occupational Health and Safety 
International Refereed Academic Journal of Sports, Health and Medical Sciences April - May - June Issue: 31 Spring Summer Semester Year: 2019

Uluslararası Hakemli Akademik Spor Sağlık ve Tıp Bilimleri Dergisi

Nisan - Mayıs - Haziran Sayı: 31 İlbahar Yaz Dönemi Yıl: 2019 ID:448 K:475

ISSN Print: 2146-8508 Online 2147-1711

(ISO 18001-OH-0090-13001706 / ISO 14001-EM-0090-13001706 / ISO 9001-QM-0090-13001706 / ISO 10002-CM-0090-13001706) (TRADEMARK)

(2015/04315- 2015-GE-18972)

\section{DISCUSSION}

People spend a large part of their times at the place of work. One of the important factors affecting the success of the workplaces is the employees. In this context, job satisfaction has an important role that affects the economic situation of the employees as well as their psychological status (Can and Soyer,2009). As a result of the high performance of the employees, high quality products, high sales, high profit and investment opportunities arise (Akar and Yildirım,2008).Due to the rapid progress of technology, mechanization, new production methods and the weakening of the feeling of belonging to the workplace, not taking adequate precautions against it causes the increase of occupational accidents and occupational diseases. Initial research on job satisfaction dates back to the 1930s (Gül,et al.,2008; Lenhardt and Beck,2016). Researchers have measured job satisfaction with different aspects (Poyraz and Kama, 2008). Our research showed that the job satisfaction score of the occupational health professionals working in the private sector was found to be significantly higher than the state employees. We believe that this result is due to the fact that job satisfaction is related to working conditions such as responsibility, diversity of tasks and communication. In addition, we estimate that the job satisfaction score is higher for the employees in the private sector due to higher chances of promotion and higher wages. We measure job satisfaction through an elite survey with a sample of 300 graduate students with a degree in Occupational Health and Safety. We operationalized our approach to job satisfaction through this and found that job satisfaction is higher among occupational health and safety expertise who had different certificate (B and $\mathrm{C}$ group certificate). In our study, there is no difference between the gender and marital status for the job satisfaction score. In 2017 Karakaya et al. obtained similar results in a study of occupational health and safety specialists.

According to legal regulations in Turkey, Bclass occupational health and safety specialists (OHSS) must work in hazardous enterprises. In order to be a class $\mathrm{B}$ specialist, it is required to have worked as a $\mathrm{C}$ class specialist for at least 4 years and to be successful in the examinations conducted by the Ministry of Labor and Social Security. In this respect, B-class OHSS experts work in more qualified and higher wage jobs and for these reasons, we think that the job satisfaction score is higher.

As a close look at Table 2 shows that the present study found that highest satisfaction with the questions posed about job satisfaction were opportunity to keep a permanent job position (C group), opportunity to help others (C group), opportunity to work accord- 


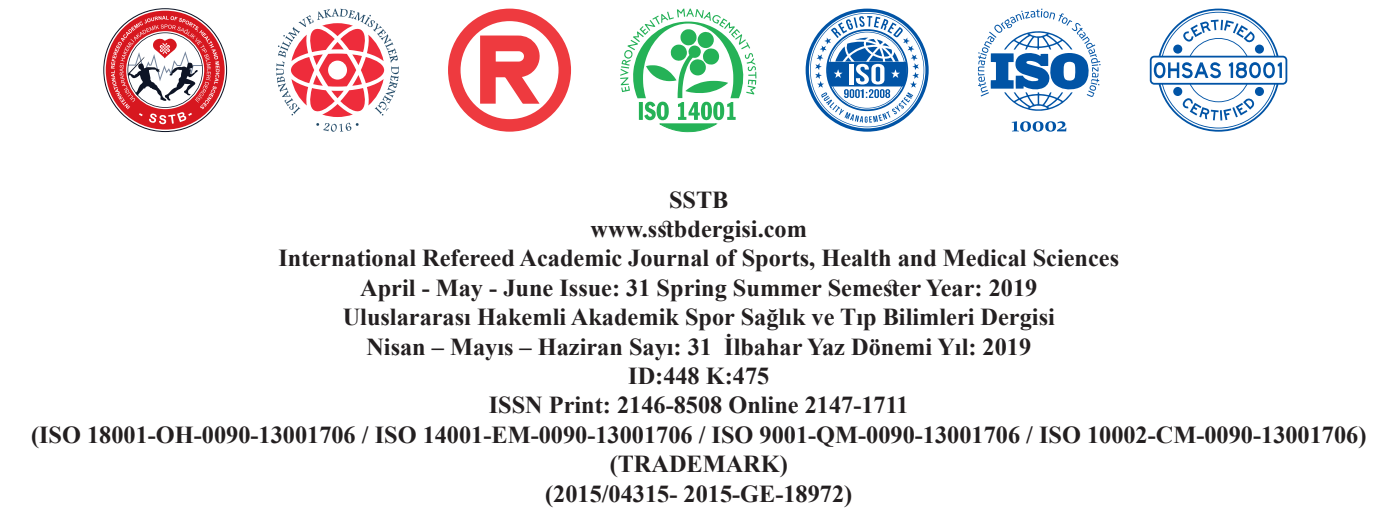

ing to one's own ethical values ( $\mathrm{C}$ group) (12 points, 10 points and 10 points respectively). Again in Table 2, the lowest scores were found as, opportunity for career development (B group), appreciation in the business (B group) and manager's attitude toward workers (B group) (10 points, 9 points and 9 points respectively).

\section{CONCLUSION}

The distribution of the points varies between less-satisfied to satisfied, which means a median distribution of medium-satisfied in general. The meaning of this normal distribution is positive attitude of occupational health and safety specialists about their job satisfaction. Group B is more optimistic about their job satisfaction and future career, while Group C is more cautious about their future prospects and possible guidance of others. This can be explained by training period and examinations conducted by the Ministry of Labor and Social Security. The findings suggest the need for a better motivation and a smoother process for Group $\mathrm{C}$ in health and safety business. This study underlines that job satisfaction is a major issue among the Specialists and point out to the necessity of further research to unfold the dynamics of job satisfaction within this group. Although the analysis of an elite group of 300 graduate students with a relevant degree may have limitations in terms of a more universal understanding of this is- sue in Turkey, one would safely agree that the findings based on survey data provides reliable results for underlining major trends and for further study in this vital area of safety and health of work life.

\section{RECOMMENDATIONS}

Because of the time and communication restrictions this study was applied only to the master students of Istanbul University Occupational Health and Safety Program and they also work as a Occupational Health and Safety Specialist. Similar study can be apply to all Occupational Health and Safety Specialists in Turkey to obtain more comprehensive results.

\section{REFERENCES}

AKAR, C., YILDIRIM, T.Y., (2008). The relationships among organizational commitment. Job satisfaction and role stressors of managers: an area application in white meat (poultry and fish) sector with structural equation model. Gazi University Journal of Economic and Administrative Sciences, 10(2):97-113

ALALI, H., BRAECKMAN, L., HECKE, T.V., WAHAB, M.A., (2018). Shift work and occupational accident absence in Belgium: findings from the sixth European working condition survey. International Journal of Environmental Research and Public Health. 15(9):1811 
International Refereed Academic Journal of Sports, Health and Medical Sciences April - May - June Issue: 31 Spring Summer Semester Year: 2019

Uluslararası Hakemli Akademik Spor Sağlık ve Tıp Bilimleri Dergisi

Nisan - Mayıs - Haziran Sayı: 31 İlbahar Yaz Dönemi Yıl: 2019 ID:448 K:475

ISSN Print: 2146-8508 Online 2147-1711

(ISO 18001-OH-0090-13001706 / ISO 14001-EM-0090-13001706 / ISO 9001-QM-0090-13001706 / ISO 10002-CM-0090-13001706) (TRADEMARK)

ARSLAN, V., ULUBEYLI, S., (2016). A field research for problems of occupational safety experts. Bülent Ecevit University. Journal of Work and Society, 3:13211340

AYDIN, U., (2013). The role of occupational health and safety training in occupational accident and diseases. Cement industry employers' association, 27 (4):24-45

CAN, Y., SOYER, F., BAYANSALDUZ, M., (2009). Examining the relationship among sportment's work satisfaction and organizational and leader commitment feelings. Niğde University Journal of Physical Education and Sport Sciences, $3(3): 228-238$

DURDU, H.I.., (2014).Economical analysis of work accidents and the assasment in some sectors. Social Security Journal, Number: 5

E ĞINLI, A.T., (2009). Job satisfaction in employees: public and private sector a research on job satisfaction of employees. Atatürk University Journal of Economic and Administrative Sciences, 23(3):35-52

GÜL, H., OKTAY, E., GÖKÇE, H., (2008). Analysis the relationship between job satisfaction, stress, organizational commitment, intention to leave and performans:in the health sector application. Academic Outlook, 15: 1-11

KARAKAYA, A., SANCI, V., (2017). A study on job satisfaction of occupational safe- ty experts:The Black Sea Region case. Karabük University Journal of Social Sciences Institute, 7(1):3-13

LENHARDT, U., BECK, D., (2016). Prevalence and quality of workplace risk assessments - findings from a representative company survey in Germany. Safety Science, $86: 48$

NARTER, S., (2015). The criminal liability of members of the legal entity in the occupational accidents and occupational disease. Journal of Economic and Administrative Sciences, 17 (2):229-266

ÖÇAL, M., ÇIÇEK, Ö., (2017). Comparative analysis of occupational accidents data in Turkey \& EU. HAK-İŞ International Journal of Labour and Society. 6 (16):616-637

PEKŞEN, Y., (2017). General approach to health employee, proffessional diseases and occupational accident concepts. 19 May University Medicine Faculty. Department of Public Health, 3(2):49-57

POYRAZ, K., KAMA, B., (2008). Analyzing the effect of perceived job security on job satisfaction organizational loyalty and invention to leave. Süleyman Demirel University Journal of Economic and Administrative Sciences, 13 (2):143-164

SAI, J., BRUCK, A., (2009). Sociocultural contexts and worker safety and health. AAOHN Journal. 57(2):51 
SSTB

www.sstbdergisi.com

International Refereed Academic Journal of Sports, Health and Medical Sciences

April - May - June Issue: 31 Spring Summer Semester Year: 2019

Uluslararası Hakemli Akademik Spor Sağlık ve Tıp Bilimleri Dergisi

Nisan - Mayıs - Haziran Sayı: 31 İlbahar Yaz Dönemi Yıl: 2019 ID:448 K:475

ISSN Print: 2146-8508 Online 2147-1711

(ISO 18001-OH-0090-13001706 / ISO 14001-EM-0090-13001706 / ISO 9001-QM-0090-13001706 / ISO 10002-CM-0090-13001706) (TRADEMARK)

(2015/04315- 2015-GE-18972)

YILMAZ, T., (2014). Investigation of the relationship between job satisfaction and motivation levels of employees: a research on public workers. Gazi University Institute of Education Sciences, Department of Office Management Education, Master's Thesis, Ankara

\section{INTERNET RESOURCES}

http://www.vergivekanunlar.com/is-saglgve-guvenligi-yasas-5-isverenin/(Date Accessed:30.06.2018) 